\title{
The Effects of the Black Death on International Relations During the Renaissance Period Compared with the Covid-19 in 2020
}

\author{
Grace Wenjie Fang ${ }^{1, *}$ \\ ${ }^{1}$ The international division of No.2 High School, East China Normal University, Shanghai, China, 200000
*Corresponding author. Email: hsefz@hsefz.cn
}

\begin{abstract}
In 2020, a new kind of coronavirus suddenly spread from Wuhan to the whole world. Then the cities were blockaded, and the whole nation was alerted. Social media have begun to call COVID-19 as "modern plague". Compared to 1340s, a plague that swept across Europe called the Black Death killed 25 million Europeans, a third of the total population of Europe at that time. The Renaissance was supposed to be prosperous, so did the arrival of the black death affect the European economy? Is the impact positive or negative? In addition, it disintegrated the serfdom system, but at the same time, it led to significant changes in the European economic system. This paper will explore the similarities and differences between the covid-19 2020 and the black death in medieval Europe in international relations.
\end{abstract}

Keywords: renaissance, black death, covid-19

\section{INTRODUCTION}

The Renaissance influenced the whole process of European history and all aspects of European society. The rise and development of the Renaissance has its own background. The Black Death played a great role in promoting the Renaissance. The black death broke out in Europe in the 14th century and objectively became the booster and catalyst of the Renaissance. It was the accidental emergence of the black death that threatened the church authority that was deeply rooted in Europe. In Europe in the mid-14th century, the black death first occurred in the Caspian Sea of Central Asia, spread to the Mediterranean through the Black Sea coast and Crimea, and then spread to Europe [1]. The prevalence of the black death in Europe caused a large number of deaths in the European population, sharply reduced the social labor force, plunged the whole European social order into turbulence and chaos, promoted the disintegration of serfdom, and made profound changes in the European economic system and structure.

The Black Death arrived in Europe in September 1347 , an infected person will initially develop a tumor on his body and then spread quickly throughout his body. Finally, several large black spots or purple spots will appear on the patient's body, and then go to death. The most disturbing similarity between the two is not the disease itself, but its social consequences. At that time, as now, many people blamed some races for the outbreak.

\section{INFLUENCES ANALYSIS}

\subsection{Changes in the structure of society}

At the beginning of the outbreak of the black death, the Catholic Church ruling Europe could not explain this phenomenon. It could only be said that it was condemned by heaven, that is, the black death was God's punishment on the world. The only way to stop the plague is to pray and repent of their past sins. However, people soon found that in the face of the fierce black death, any prayer and confession were invalid. Even the high Catholic priests are not spared. People began to rethink and pursue religion. From this point of view, the black death also promoted religious reform.

In the shadow of the plague, the neighbors did not communicate with each other and avoided it. In many cities, it is believed that the plague was caused by Jews poisoning the water. Jews were therefore subjected to particularly serious inhuman treatment. A large number of Jews were either forced to migrate or brutally killed. As the plague raged and the traditional religious response failed, the flagella movement appeared in Austria in 1348 and spread to Germany and Flanders in 1349. Flagellants 
consists of groups of Christians, led by a master, they roamed from one town to another, whipping themselves for their own sins and forcing communities in the persecution and slaughter of Jews, gypsies [2].

In terms of social status, the status of businessmen and financiers began to be higher than that of aristocratic Lords. The rebirth of urban economy provided a carrier for the development of capitalism and became the pioneer of Europe from the Middle Ages to modern society. The occurrence of the Black Death changed the old social structure and promoted the great development of capitalism.

\subsection{Impacts of black death on Economy}

In the short term, it can be seen that a large number of people died due to the black death, which led to a serious shortage of social labor force, which led to the decline of the overall trade scale and productivity level of society. The increase of mortality caused by the Black Death pandemic directly led to the sharp reduction of social labor supply. Under the sudden blow, people are helpless and can only passively live a life of resignation. Watching people fall one by one, people lose their plans and hopes for the future. Farmers in the countryside, knowing that their time of death has come, are no longer willing to engage in labor. Therefore, from 1349 to 1351, there was a general famine caused by barren land.

After 1353, even though there was a famine, people found that prices fell. Because many people died in the plague, they left land, houses and other ownerless wealth, which were inherited by the survivors. Therefore, there are fewer consumers, and the remaining products need to be sold at a lower price. But this is temporary. When the remaining products are consumed, prices will rebound sharply, resulting in a more serious shortage crisis. The underlying reason for this result is that although demand has decreased, it also means that the number of people engaged in production has decreased sharply. At the beginning, people can still enjoy the low price of surplus products, but after a few months, when the surplus products are consumed, and the productivity cannot return to the pre-epidemic level, all walks of life cannot operate normally because many people die or leave, and the price of products will soar due to shortage. Therefore, the surviving people should not be confused by the shortterm low price, think that the goods reserve is sufficient, and rest assured [3].

But people are always short-sighted. After suddenly inheriting their next industry, they are like upstarts, wantonly squandering, drinking and eating. In particular, the plague has caused trauma to people's mind. They believe that they must enjoy life in time. The survivors found that individuals were indeed richer than before, but the whole of Europe was poorer. When the remaining products are consumed, the disaster of product shortage and soaring prices will come. The death of most people led to the redistribution of social wealth, and the wealth gap in Europe began to grow. Britain, a great example, compared with other European countries, its economic development was relatively backward, particularly affected by Black Death and the hundred year war, the crises England encountered seemed even graver.

On the other hand, affected by the new crown epidemic, the European economy shrank in the first half of 2020, and a number of economic data hit a historic low. In order to support people's livelihood, the European Central Bank and the European Union have introduced a series of rescue measures to avoid the outbreak of the economic and financial crisis. However, the European economy will still face many challenges and risks, and it is difficult to fundamentally reverse the trend of falling into recession within this year. Whether the European economy can get out of the predicament in the future will depend on whether the EU can successfully realize economic and strategic transformation, effectively maintain the global trading system under multilateralism, and further deepen China EU economic and trade cooperation.

According to the estimation of the International Monetary Fund (IMF), the GDP growth rate of the Eurozone will be $-7.5 \%$ in 2020 , and the contraction will catch up with the end of World War II.

The recurrence of the epidemic has led to the rise of unemployment again, and many companies are also facing the risk of bankruptcy. Despite the active support of monetary and fiscal policies, the European economy will still face great downward pressure after the gradual resumption of work, which is mainly caused by three reasons: first, there is still some uncertainty in the development of the epidemic. Secondly, it also takes time for the policy to show its effect on economic stimulus. Finally, the structural problems of the European economy itself have not improved.

Moreover, the IMF pointed out that the imbalance in global vaccine distribution will exacerbate global inequality. The economic growth rate of high-income countries will return to $4.3 \%$ in 2021 , while many lowincome countries (especially African countries) will not be able to return to the pre epidemic economic growth level until 2022-2024. Covid-19, the world's poorest population (earning less than US $\$ 1.90$ per day) has reached a new high of 20 years, an increase of about 120 million, according to world bank data.

\subsection{Impacts of the black death on science and technology}

At first, the black death caused many Italians to be infatuated with death. The dance of death was a popular theme in art and architecture at that time. The general mood was pessimism, but there was also an culture that 
opposite from that, which was, the desire for a happy and stable life.

This senses that life was fleeting and every kind of happiness should be grasped prompted many Italians to seek comfort in art and literature, which was also one of the factors in the development of the Renaissance. Many elites were eager to enjoy life, which led them to pay more attention to art. This also led to the change of the artist's theme. Religious themes gradually became less popular, and people began to have a strong interest in secular themes, especially those from the classical world. From the comparison between Giotto and Botticelli, we can see the new interest in secular themes. Giotto painted almost only religious paintings. Although Botticelli painted secular and religious themes, his most famous works were his secular works, such as Primavera.

\section{THE INFLUENCES OF THE BLACK DEATH ON WESTERN MEDICINE}

During the outbreak of the black death, doctors believed that the plague was mainly transmitted through the air according to the traditional medical theory. Therefore, they proposed that the first way to resist the plague was to choose a place where the air was not infected by the plague, purify the deteriorated air and avoid contact with the people infected with the plague. Agramont recommends avoiding discarding animal offal near towns. Doctors also put forward many suggestions on diet, exercise and sleep. For example, if you want to eat healthy food that is easy to digest, the water you drink must be clean and flowing.

However, the above measures have no effect, so people begin to doubt the authority and pay more attention to the experience from practice. When the black death first appeared in Europe, people knew nothing about it and seemed a little helpless when it was rampant. An anonymous author said, "since such a plague. Never before have people seen medical authorities, Hippocrates and others come together, and there is no way to do it [4].

In the great surgery written in 1363, Guydechauliac changed his attitude from pessimism to optimism and put forward many measures to treat the plague. And no longer listen to fate. Before the outbreak of the black death, the living environment in Europe was very poor. At that time, there was an extreme lack of health and transportation facilities in both towns and villages. "Population movement, business exchanges and the rise of urbanization centers made the cities in medieval Europe extremely crowded and piled with garbage. The public health situation is not bad. After the outbreak of the black death. In Italy, there are health committees and laws on public health. In 1361, the black death made a comeback. At the beginning of the 15 th century, Venice established a permanent public health committee to supervise the regional medical practice and observe the local health situation. Some cities specially set up government doctors to control the epidemic. People pay more and more attention to medicine, and there are detailed regulations on the depth of body burial.

Although these practices are very necessary from today's perspective, many difficulties were encountered at that time. These need the help of the government to achieve, but also to prevent dereliction of duty and abuse of power. And not all the people cooperate. In fact, many urban residents are very dissatisfied with the restrictions imposed on them. A member of Milan's public health committee wrote that "we are hated by ignorant people. They listen to the words of several doctors who do not care about public health but repeatedly say that there is no plague problem. When we accidentally pass through the narrow streets of residential areas, people abuse us with dirty language and even throw stones at us" [5].

The plague was so violent that no one could help, so people died in pain. Today, however, much progress has been made because of our understanding of history and the experience gained from many other plagues.

\section{COMPARISON BETWEEN THESE TWO PLAGUES}

Like COVID-19, the black death is a disease of indiscernible, it evolved from the East, spread among the urban population, and even spread to different countries through international trade. Because medicine was not developed at that time, avoiding contact with contaminated objects and infected people was the only way to escape disease. Therefore, some areas prohibited foreigners from entering their provinces at that time [7]. In the contemporary world, isolation is also a major way to reduce COVID-19's spread. Although both are historic disasters, they also bring unexpected benefits.

\section{CONCLUSION}

Through the research, it can be found that both the black death and today's epidemic have brought a great impact on the society, especially the economic and social structure. Now, because of COVID-19's rapid economic recession, people are facing unemployment and a large number of companies have also declared bankruptcy. But with the progress of medical treatment, people are no longer at a loss. The vaccine was quickly developed, and the improvement of isolation measures reduced the number of deaths and infections. Also, during and after the black death, significant advances in science and technology provided a new way of thinking for the Renaissance [8].

\section{ACKNOWLEDGMENTS}

Finally, I would like to thank the professor for giving us so much time to explain the topic of international 
relations this month. Thank the teaching assistant for giving targeted opinions on the topic of my thesis. In addition, I thank my friends for bringing me positive inspiration and encouraging me all the time. During this time, we learned from each other, helped each other and spent an unforgettable time together.

\section{REFERENCES}

[1] Ben Davis, How did the black plague contribute to the Renaissance and Reformation? - MVOrganizing. May 18, 2021. https://www.mvorganizing.org/howdid-the-black-plague-contribute-to-the-renaissanceand-reformation/

[2] P Temin, What does the Black Death teach us about development? June 4, 2016. https://www.weforum.org/agenda/2014/06/blackdeath-teaches-development/

[3] G Clark, The Economics of the Black Death, Microbes and Markets: Was the Black Death an Economic Revolution? [J] Demographic Economics June 2016, Vol. 82, No. 2, pp. 139 -165.

[4] G Jianhong, The influence of black death on the development of Western Medicine [J] East China NOrmal University Press, 2015, pp. 96-100.

[5] Ali Shamekh \& Ata Mahmoodpoor \& Sarvin Sanaie, COVID-19: Is it the black death of the 21st century? Jul 12, 2020. https://www.ncbi.nlm.nih.gov/pmc/articles/PMC74 20170/

[6] UN, COVID-19 response demands better use of science and technology, April 22, 2020. https://www.un.org/development/desa/en/news/poli cy/covid-19-response-demands-better-use-ofscience-and-technology.html

[7] $\mathrm{R}$ Levine, THE BLACK DEATH \& THE UNEXPECTED BENEFITS TO SOCIETY. https://opentextbooks.clemson.edu/anne1/chapter/t he-black-death-and-medical-advances-

2/\#: :text=The $\% 20$ science $\% 20$ and $\% 20$ technology $\% 20$ that $\% 20$ was $\% 20$ prominent $\% 20$ during,of $\% 20 \mathrm{t}$ hinking $\% 20$ that $\% 20$ paved $\% 20$ way $\% 20$ into $\% 20$ the $\% 20$ Renaissance.

[8] H Campbell, How The Bubonic Plague Made Europe Great, June 9, 2008. https://www.science20.com/science_20/how_bubo nic_plague_made_europe_great-293781 